\title{
Lateral migration of explosive hazards during maar eruptions constrained from crater shapes
}

\author{
A. H. Graettinger ${ }^{*}$ (D) and A. T. Bearden
}

\begin{abstract}
Maar volcanoes are produced by subsurface phreatomagmatic explosions that can move vertically and laterally during an eruption. Constraining the distances that maar-forming explosions move laterally, and the number of relocations common to these eruptions, is vital for informing hazard scenarios and numerical simulations. This study uses 241 intact Quaternary maar crater shapes to establish global trends in size and spacing of explosion position relocations. Maar craters are sorted into shape classes based on the presence of uniquely identifiable combinations of overlapping circular components in their geometry. These components are used to recognize the minimum number of explosion locations responsible for observed crater shapes. Craters with unique solutions are then used to measure the size and spacing of the explosion footprints, the circular area of the largest crater produced by a single explosion of a given energy, that produce the crater shape. Thus, even in the absence of abundant observations of maar-type eruptions, the typical range, size and spacing of explosion positions are derived from maar crater shapes. This analysis indicates that most Quaternary maar eruptions involved at least three different explosion locations spanning distances of 200-600 $\mathrm{m}$ that did not always follow the trend of the dike feeding the eruption. Additional evaluation of larger maars, consistent with stratigraphic studies, indicates that centers of explosive activity, and thus the origin of ballistic and density current hazards, can move as many as twenty times during a maar-forming eruption. These results provide the first quantitative constraints on the scale and frequency of lateral migration in maar eruptions and these values can directly contribute to hazard models and eruption event trees in advance of future maar-type eruptions.
\end{abstract}

Keywords: Phreatomagmatism, Shape analysis, Migration of hazard source, Crater shape

\section{Introduction}

\section{Lateral movement of explosions in maar-forming} eruptions

Maars are small-volume volcanic landforms produced by subsurface phreatomagmatic explosions that excavate a crater that cuts into the pre-eruptive surface (White and Ross 2011). Their craters provide an opportunity to investigate the processes and hazards resulting from explosive magma-water interactions. Observations of the

\footnotetext{
*Correspondence: graettingera@umkc.edu

University of Missouri Kansas City, 5110 Rockhill Road, Kansas City, MO 64110, USA
}

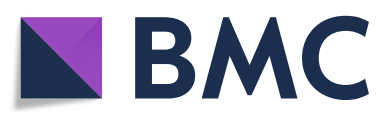

(c) The Author(s). 2021 Open Access This article is licensed under a Creative Commons Attribution 4.0 International License, which permits use, sharing, adaptation, distribution and reproduction in any medium or format, as long as you give appropriate credit to the original author(s) and the source, provide a link to the Creative Commons licence, and indicate if changes were made. The images or other third party material in this article are included in the article's Creative Commons licence, unless indicated otherwise in a credit line to the material. If material is not included in the article's Creative Commons licence and your intended use is not permitted by statutory regulation or exceeds the permitted use, you will need to obtain permission directly from the copyright holder. To view a copy of this licence, visit http://creativecommons.org/licenses/by/4.0/. The Creative Commons Public Domain Dedication waiver (http://creativecommons.org/publicdomain/zero/1.0/) applies to the data made available in this article, unless otherwise stated in a credit line to the data.

maar-forming Ukinrek 1977 eruption in Alaska (Kienle et al. 1980) showed that the eruption was not focused at a single position but instead migrated laterally through time. The eruption also showed that multiple vents could erupt simultaneously and have contrasting eruption styles. This lateral migration of vent locations has also been reconstructed from the stratigraphy of maar tephra rings from around the globe (Ort and Carrasco Núñez 2009; Van Otterloo et al. 2013; Lopez-Rojas and Carrasco-Núñez 2015; Fierstein and Hildreth 2017). Geophysical studies of the diatremes underlying maar craters in the Newer Volcanic Province Australia have 
revealed complex diatreme structures that also reflect multiple vent locations from a single eruption (Jordan et al. 2013; Blaikie et al. 2014). This study will investigate the way that steps of this migration, relocation of explosion loci, are also recorded in the shape of maar craters that display compound shapes of overlapping explosion footprints, where a footprint is defined as the maximum circular crater produced by a subsurface explosion of a given energy (Fig. 1).

Lateral movement of explosion locations causes variability in the extent of hazard impacts that is not yet incorporated into phreatomagmatic eruption scenarios. Most hazard assessments and eruption scenarios that include phreatomagmatism only indicate that it is possible to have a phreatomagmatic phase (Ang et al. 2020). The absence of additional detail related to variations related to phreatomagmatic activity is due to the lack of quantitative constraints on the distance over which this migration has occurred in past eruptions and estimates of the number of times explosion epicenters laterally shift during an eruption. This study uses an expanded MaarVLS (Maar Volcano Location and Shape) database of intact Quaternary maars (Graettinger 2018) to estimate 1) how often do explosion locations move laterally in maar-forming eruptions? and 2) how far do the locations shift? In the process of evaluating these first two questions, it becomes possible to consider the size of the footprint from each individual explosion position, which provides insight into what may be common explosion sizes in these eruptions. These values can contribute to hazard models and eruption event trees in advance of future maar-type eruptions or eruptions from smallvolume volcanoes that have the potential for phreatomagmatic contributions.

\section{Background-linking crater shapes to explosion positions}

A maar crater shape is produced through a combination of explosive excavation and collapse. Maars sit on top of a downward-tapering diatreme filled with fragmented juvenile and country rock material (White and Ross 2011;
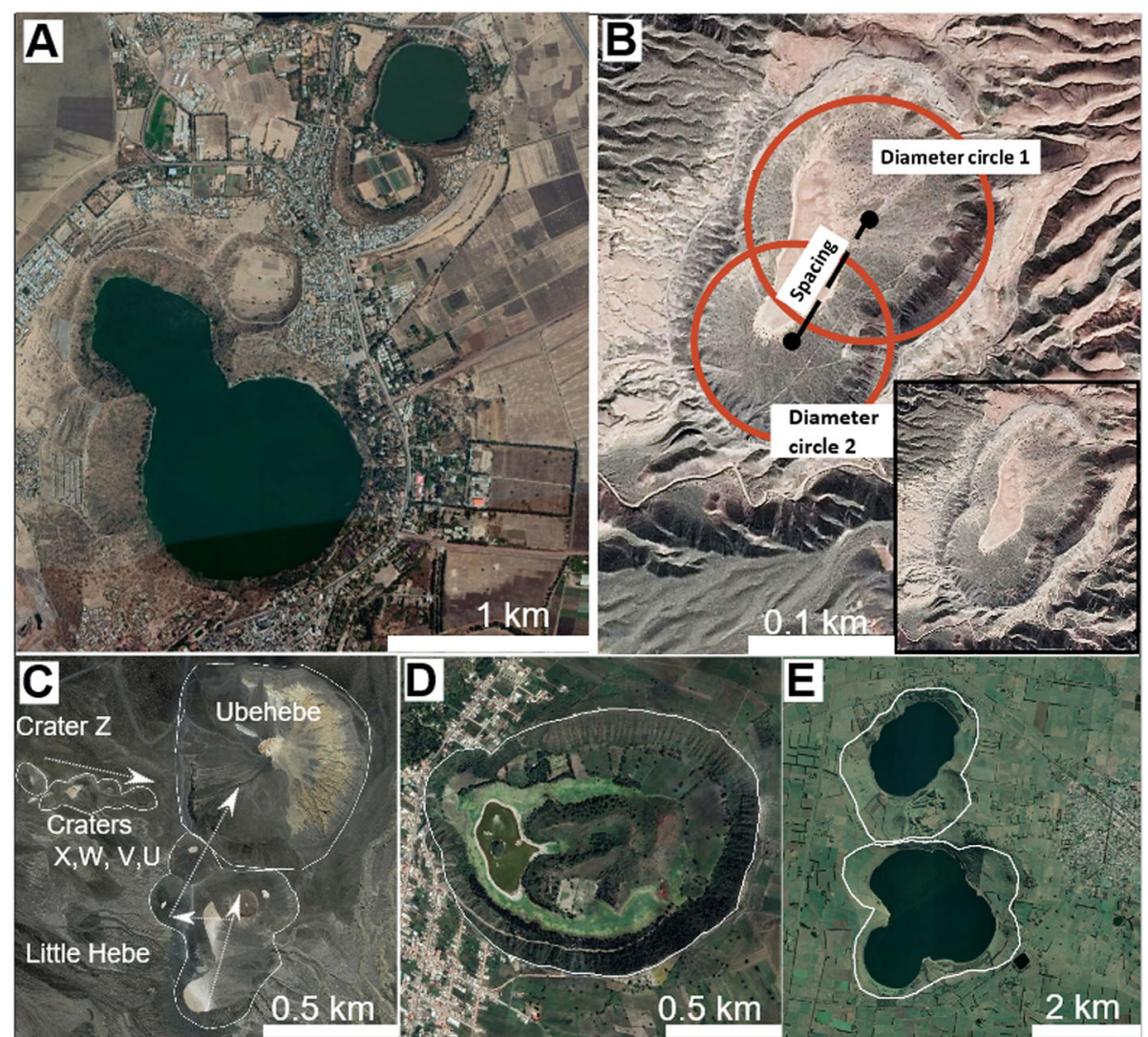

Fig. 1 Maar shapes: a Hora and Kiroftu Lakes, Bishoftu Volcanic Field, Ethiopia retain clear circular elements to their shape even without annotation. b Peanut-shaped maar from Qal'eh Hasan Ali volcanic field, Iran with footprint (red) superimposed with unannotated inset. c-e Maars with rim outlined in white. c Ubehebe crater complex shows a range of shapes and sizes produced from lateral migration of explosion locations (adapted from Fierstein and Hildreth 2017). d Tecuitlapa, Mexico, has an unsymmetrical ellipsoidal shape with a small scallop from collapse. e Bullen Merri and Gnotuk from the Newer Volcanic Province, Australia have circular elements, but do not have a unique solution. Images from Google Earth. Maxar Technologies, CNES/Airbus, Landsat/Copernicus 
Valentine et al. 2017). The energy released from a subsurface explosion travels outward in three dimensions around a central point. Where that sphere of disruption arrives at the surface of the earth, the circular intersection defines the crater. An explosion footprint is defined as the maximum circular crater produced by a subsurface explosion of a given energy (Valentine et al. 2015). The resulting footprint can expand through collapse of portions of the crater rim, or commonly around the entire crater perimeter. Lateral migration of subsurface explosion locations results in compound craters with shapes that are the product of multiple overlapping explosion footprints.

Meter-scale cratering experiments involving buried chemical explosives produced circular craters through stationary explosion positions, and compound shapes from laterally migrating explosion positions (Valentine et al. 2015). Stationary experiments determined that explosions of a given energy at an optimal scaled depth that are located under the same epicenter can increase the size of the crater up to a certain maximum diameter (Sonder et al. 2015). Only a portion of this asymptotic growth is the direct result of excavation where explosive jets lift and transport crater rim material. With continued explosions at the same optimal scaled depth, latestage growth is dominated by circum-crater collapse of the rim associated with explosions in which the diameter of jets produced is less than the crater diameter (Graettinger et al. 2016). Growth stops when the final crater rim is outside the influence of the explosion and thus continued growth related to explosive activity can only happen if the explosion location migrates or the energy of the explosion increases (Sonder et al. 2015).

For experimental craters in which the explosion position relocated laterally, the spacing between the explosion footprints (Valentine et al. 2015) and relative size of the involved footprints, controlled the final shape of the resulting crater. During experiments when footprint spacing increased up to one footprint radius, the resulting shape became elliptical. As the footprint spacing distance exceeds the footprint radius, the resulting crater shape resembles overlapping circles (Fig. 2). Footprint spacing greater than two times the crater radius produces separate craters, referred to here as crater complexes.

These relations can be used to evaluate the minimum number and relative position of overlapping explosion footprints required to produce observed maar crater shapes. Figure 2 displays the range of shapes produced by overlapping explosion footprints for which the footprints are the same size. When explosion footprints are not the same size and still overlap by less than the

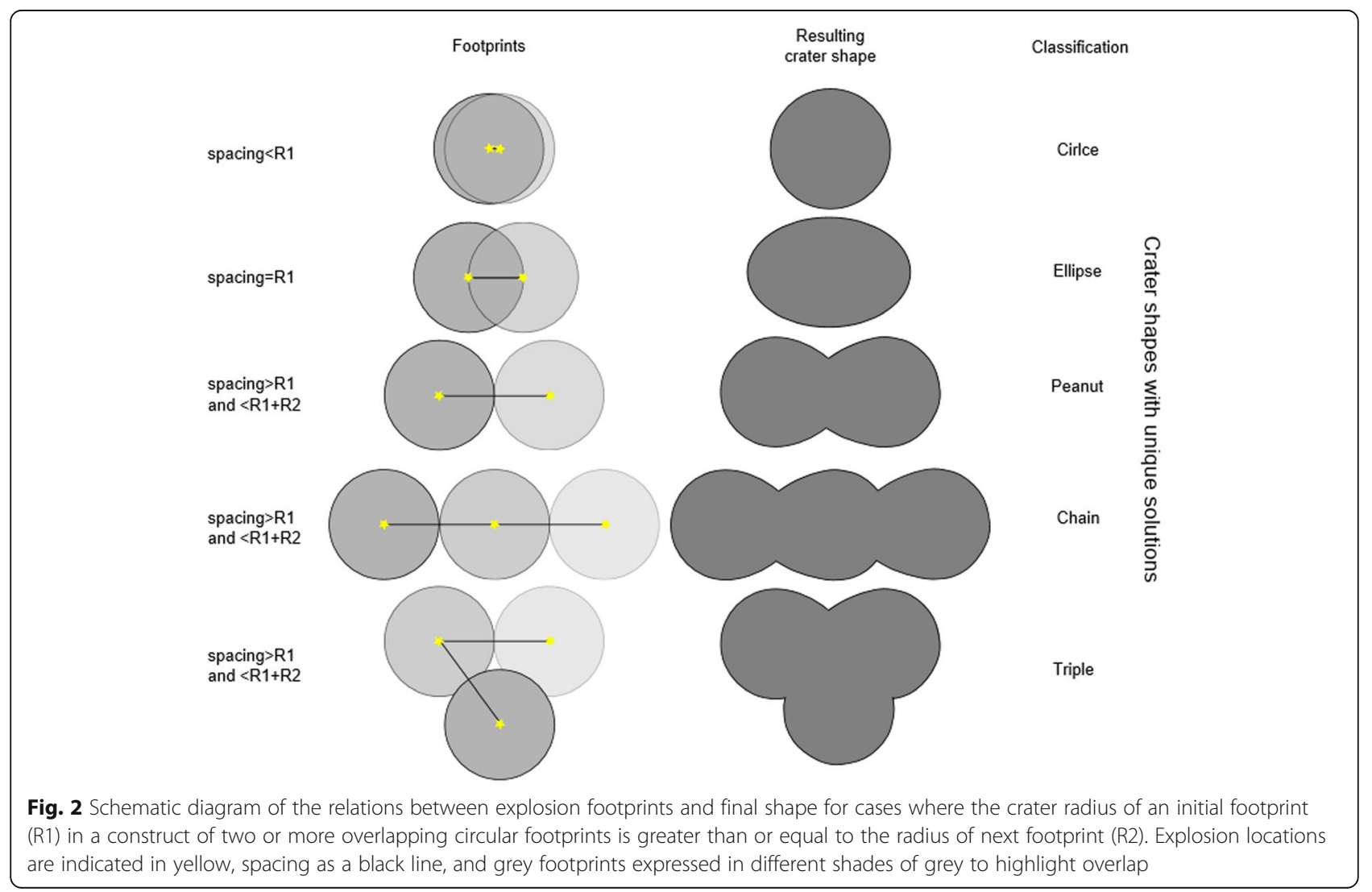


combination of $\mathrm{R} 1$ and $\mathrm{R} 2$, the resulting shape will be asymmetrical along at least one axis.

The adaptation of this theoretical framework to natural maars requires a brief comment on processes other than shallow explosions that influence maar shape. Pirrung et al. (2008) noted that in the decades following formation, the Ukinrek craters in Alaska increased in size, but the proportions (notably aspect ratio of major and minor crater diameters) were maintained and thus the shape of craters with intact rims is still relevant for the analysis done here (Graettinger 2018). Localized slumps on maar crater rims have been recognized, such as Tecuitlapa, Mexico, but for maars where unique solutions are identifiable, the arc shaped modification of the rim by slumping is typically smaller in scale $(\approx<10 \%)$ than the overall curvature of the crater shape (Fig. 1D), and not distinct enough to be counted as an explosion footprint (Ort and Carrasco Núñez 2009). More extensive modification of a crater rim (multiple collapses, fluvial incision, permafrost degradation) would similarly not produce large overlapping circular geometries that contribute to unique footprint solutions required for this analysis. Similarly, some non-circular maar shapes have been previously interpreted as the result of a structural influence augmenting collapse (Joya Honda, Mexico; Aranda-Gomez and Luhr 1996). However, numerous stratigraphic studies have used circumcrater ejecta variations and crater shape to recognize multiple vent positions, so that the positions are commonly reconstructed to correlate with circular components in the crater outline (Aranda-Gomez et al. 1992; Fierstein and Hildreth 2017).

Finally, not all subsurface phreatomagmatic explosions contribute to crater growth and eruptive jets (Lefebvre et al. 2013; Sweeney and Valentine 2015; Graettinger et al. 2014). The explosions that excavate craters and erupt at the surface are typically shallow $(<200 \mathrm{~m})$ explosions (Valentine et al. 2014). Therefore, this paper will use maar crater shape to estimate the minimum number of explosions and lateral shifts in explosion positions to produce the observed crater shape. It does not account for decreases in explosion energy or deeper explosions, or explosions that occur in previously occupied locations. Even with such limitations, these values have been previously unavailable, and thus maar crater shape analysis provides a valuable opportunity to provide new quantitative constraints for hazard models and eruption scenarios in advance of future maar-forming eruptions.

\section{Methods}

This study utilizes an expanded MaarVLS database (Graettinger 2018) comprising Quaternary maars with rims that are at least $75 \%$ complete, and limited visible human modification. Maars added to the database were from VOLADA - The Volcanic Lake Database (Rouwet and Chiarini 2013), resulting in a total of 241 monogenetic features suitable for shape analysis. The majority of maars in the database are considered monogenetic, that is the result of short duration eruption that occurred over a period of days to $<100$ years (Nemeth and Kereszturi 2015). The $4 \%$ of the maars considered to be polygenetic, here defined as maars with evidence of multiple eruption deposits separated by a paleosol, were excluded from this analysis as the population was too small to be able to evaluate the influence of this break in time on shape analysis. For features composed of a group of multiple craters whose depressions are separated by closed rims but are related to the same eruption, here called crater complexes, the individual craters presenting a single closed rim were analyzed separately (i.e. Ubehebe vs. Ubehebe chain; Fig. 1C). Additional features that were too modified to analyze are used for qualitative discussions only.

Maar crater rim outlines were manually digitized using Google Earth Imagery and ASTER Global Digital Elevation Models, and morphological parameters were collected from the resulting polygons (Graettinger 2018). For this study, crater rim lines were updated for less than $5 \%$ of the original database based on updated imagery. Morphological parameters include crater area, perimeter, major (d1) and minor (d2) diameters.

These two-dimensional measurements were then used to establish dimensionless shape parameters. Major diameter is the longest dimension of the shape that intersects the centroid, and the minor diameter is perpendicular to the major diameter, also through the centroid. Aspect Ratio (AR) is:

$$
A R=\frac{\text { Dminor }}{\text { Dmajor }}
$$

where $D_{\text {minor }}$ is the length of the crater's minor diameter and $D_{\text {major }}$ is the length of the crater's major diameter and values are less than or equal to 1 .

Elongation $(E L)$ is defined:

$$
E L=\frac{\mathrm{A}}{\pi\left(\frac{\text { Dmajor }}{2}\right)^{2}}
$$

where $A$ is the area encompassed by the crater rim as defined by the digitized polygon.

Isoperimetric circularity (IC) is defined:

$$
I C=\frac{4 \pi \mathrm{A}}{P^{2}}
$$

where $A$ is the area encompassed by the crater rim and $P$ is the perimeter of that same polygon. 
Shape analysis is built around the principle that maar crater shapes are the product of multiple overlapping explosion footprints. Maar crater rim outlines were separated into shape categories that were established based on the minimum number of circles that could be fit within the crater outline polygon. Craters are determined to either have unique solutions (circles, ellipses, peanut, chains, and triples Fig. 2), or non-unique solutions (convoluted, teardrops, and capital D-shaped craters; Fig. 3). Crater shapes have a unique solution if there is one combination of a minimum number of overlapping explosion footprints that could be used to reconstruct the crater shape, where that solution would be recognized by most researchers. The number of footprints represents the minimum number of explosion locations required to reconstruct the observed maar crater shape.

Craters with unique solutions are further subdivided into five categories (circle, ellipse, peanut, triple, and chain). A circular crater can be reconstructed using a single explosion footprint. These have an Aspect Ratio and Elongation value larger than 0.90 , and the curvature of the shape is continuous, resulting in an Isoperimetric Circularity greater than 0.90 . Circular craters can be the product of multiple explosion locations, if all explosion epicenters occur within the previous explosion footprint with a spacing between explosion locations less than that of the largest footprint radius.

Ellipses are craters with a closed curve and two directions of symmetry. The crater shape has an Aspect Ratio and / or Elongation value of less than 0.90 and Isoperimetric Circularity greater than 0.90 . This shape can be reconstructed by two similar-sized overlapping explosion footprints that are separated by a distance equal to the radius of one of the explosion footprints.
Peanut-shaped craters, or peanuts, are craters composed of two overlapping explosion footprints for which the footprint spacing is typically greater than the largest footprint radius (R1), but less than the cumulative radii of the largest and second largest footprint spacings, resulting in a characteristic shape resembling a twolobed peanut. Craters that have three or more overlapping explosion footprints in a line are called crater chains. If the three overlapping footprints are not in a line, they are called triples.

Crater shapes that do not have unique solutions are divided into three categories (teardrop, capital D, and convoluted). Teardrop craters are similar to ellipses, but do not have two directions of symmetry. The shape can be fit by a minimum of two explosion component footprints of dissimilar sizes but does not have a unique solution. Crater shapes that resemble a capital letter D lack two directions of symmetry as one crater side is straight and the shape requires a minimum of three footprints to reconstruct, though no unique solution is present. Finally, all craters that are more complicated than the previously described examples are called convoluted craters. While convoluted craters may have some clear overlapping circle components, they require at least three footprints to reconstruct and the shape cannot be resolved by a single solution of overlapping circles.

After establishing the minimum number of footprints required to reconstruct crater outlines for each category, the diameter of the footprints and the spacings between the center of the footprint are measured (Fig. 2; 1B). The number of spacing measurements will always be one less than the number of footprints. For ellipses, the minor diameter (d2) is used as a proxy for explosion footprint diameter and the epicenter of the explosion footprints

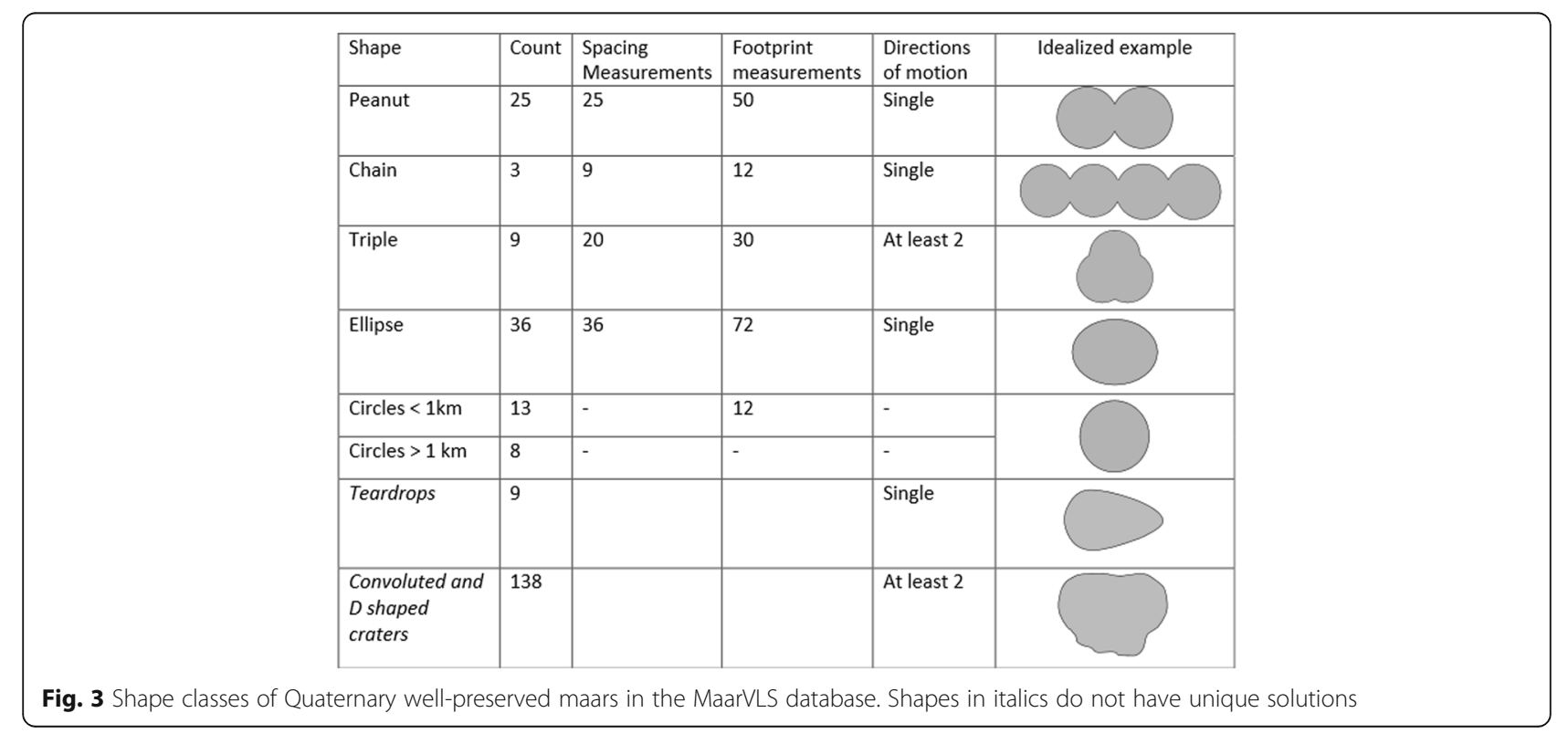


was assumed to be half of the minor diameter away from the edge of the feature along the major diameter. Thus, this makes the difference between the minor and major diameters represent the spacing between these centroids. For all craters, the direction of migration cannot be resolved from shape alone, so spacing is measured relative to the largest footprint, and then next largest footprint. In chains where footprints occur in a linear trend, spacing is measured in a single direction across the shape. We did not identify any shapes with four or more nonlinear unique explosion footprints in this database. Although crater shapes without unique solutions can be further classified by the minimum number of overlapping explosion footprints required for their shape, no measurements of explosion footprint spacing, or diameter were attempted.

\section{Results}

\section{Maar crater shapes}

From the updated MaarVLS database, 94 craters were separated into peanut, chain, ellipse, triples, and circle shapes (Fig. 3). An additional 147 shapes were considered to not have a unique solution. Evaluation of maars with available dates in the literature revealed that there was no correlation between shape and age, similar to observations in Graettinger (2018). The most common shapes with unique solutions were ellipses and peanut shapes representing a combined $25 \%$ of all maars in the database. Chains represent the least common maar shape. Several additional maar chains occur in the Nejapa Mira-Flores volcanic field in Nicaragua, but regional studies of the tephrostratigraphy indicate that both Nejapa and Ticomo maars are polygenetic (Avellan et al. 2012) and are not included in these analyses.

Non-unique shapes fall into three categories and even though there are multiple possible interpretations of overlapping footprints that could produce them, the number of minimum footprints can be estimated. Of the non-unique shapes, nine were teardrop shaped, with another six resembling the capital letter $\mathrm{D}$, and the final 141 were convoluted crater shapes (Fig. 3). Teardrops require at least two dissimilarly sized explosion footprints, and capital D and convoluted shapes both require at least three explosion locations to reconstruct. This indicates that more than half of the maars in MaarVLS require three or more explosion positions to produce the observed craters shapes.

\section{Footprint spacing}

The 94 unique maar shapes produced 90 footprint spacing measurements (circles produce no spacing measurements) [see Additional File 1.xls for full dataset of quantified maar shapes]. The database reflects a range of footprint spacing between 0.1 and $2.1 \mathrm{~km}$, with $90 \%$ of spacing values below $0.75 \mathrm{~km}$ (Fig. 4; Table 1). The average spacing across all shapes is $0.41 \mathrm{~km}$ with a standard deviation of 0.36 . Although the ellipse footprints are derived from the minimum diameter of the crater outline, the derived ellipse spacing estimates overlap with the measured values from other shapes (Fig. 4).

One clear footprint spacing mode, $0.2 \mathrm{~km}$, appears in the dataset, with common spacing distances between $0.3-0.8 \mathrm{~km}$. Small spacing distances are more common in elliptical and chain shapes than other shapes, but both have a wide range of spacing measurements. Peanuts have by far the greatest variety of spacing measurements $(0.2-2.0 \mathrm{~km})$ and triples have the least variety $(0.3-0.8$ km) (Fig. 4).

A comparison of footprint spacing with crater area shows that the largest crater shapes have footprint spacings greater than $0.7 \mathrm{~km}$ (Fig. 5). Only four maars have spacing measurements greater than $1 \mathrm{~km}$ and they are all peanuts (Fig. 4; 5). As most maars in the MaarVLS database are less than $1 \mathrm{~km}$ across (Graettinger 2018), these extreme scenarios are likely less representative of typical maar-forming eruptions.

\section{Explosion footprint sizes}

The diameters of 176 explosion footprints were derived from the 94 unique maar crater shapes. The average footprint size is $0.78 \mathrm{~km}$ (standard deviation 0.66 ) and $75 \%$ of the measured footprints are less than $1.0 \mathrm{~km}$ in diameter (Fig. 6; Table 1). A footprint size mode of 0.5$0.6 \mathrm{~km}$ is consistent across all shape types. A smaller second mode ca. $2 \mathrm{~km}$ in diameter includes peanut, circle and ellipse crater shapes. Ellipse and peanut shapes have footprint sizes across the full range of observed sizes, whereas chains have predominantly small $(0.1-0.2 \mathrm{~km})$ footprints. Triples have a narrower range of footprint sizes but have the same mode as peanuts and ellipses. Despite the variability, all maar shapes can be produced by explosion footprints less than $1 \mathrm{~km}$ in diameter.

\section{Discussion}

How many explosion relocations occur in maar eruptions? Maar crater shape analysis indicates that more than $88 \%$ of maar crater shapes in the database require more than one explosion location, with over $66 \%$ of maars in the database requiring three or more (Fig. 3). At least two chain-shaped maars are composed of four unique footprints. This approach is unable to resolve the maximum number of explosion relocations as footprints smaller than an existing crater, or footprint spacings less than one radius from the previous footprint are unresolved, but the predominance of multiple explosion locations has not been so clearly demonstrated before.

Published stratigraphic studies have reconstructed the location and number of explosion locations responsible 


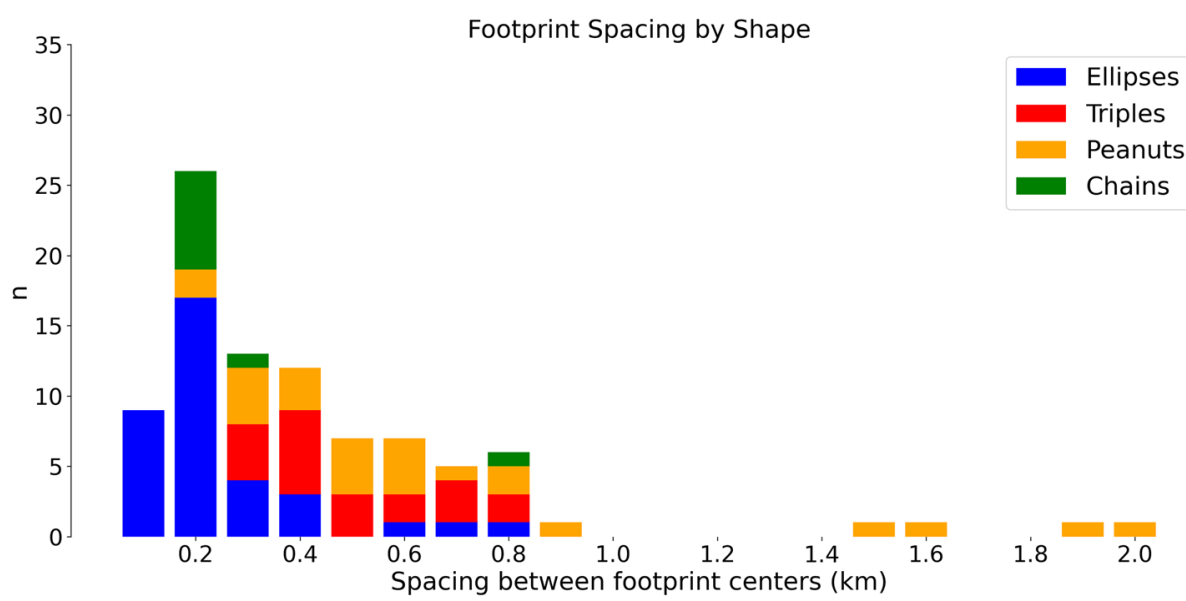

Fig. 4 Spacing measurements between component footprint centers by shape. Circles are not included as they can be resolved by a single footprint, so there are no spacing measurements

for maar tephra rings on individual compound craters included in the MaarVLS database, as well as more eroded examples (Table 2). Estimates from stratigraphic studies and historic maar-forming eruptions reflect a wide range of explosion locations from 1 to 13 positions at maar crater complexes like Ubehebe Craters (Fierstein and Hildreth 2017) and the 1970 Deception Island maars (Pedrazzi et al. 2014). Large craters without unique shape solutions like Purrumbete, Atexcac, and Tecuitlapa were reconstructed to have between 3 and 16 explosion locations (Ort and Carrasco Núñez 2009; Jordan et al. 2013; Lopez-Rojas and Carrasco-Núñez 2015). There are also intact and eroded examples of maars that have been interpreted to show limited or no lateral migration such as the circular Loolmurwak (Mattsson and Tripoli 2011) and the eroded Rattlesnake Crater (Whelley et al. 2019).

This further underscores that shape analysis represents the minimum number of explosion locations required to form observed maar crater shapes. For several of the maars analyzed here that also have detailed stratigraphic studies (Table 2), the method used here would have underestimated the number of explosion positions, including apparently simple shapes like that of Ukinrek east maar, Alaska. Importantly, stratigraphic studies reveal that each shift does not represent a unique explosion location, rather explosive activity can return to previous positions (Jordan et al. 2013; Van Otterloo et al. 2013). The eruptions reconstructed from these stratigraphic studies also record magmatic (no interaction with external water) activity from vents occupying some of the identified vent positions. Nevertheless, both the stratigraphic and shape-based techniques clearly indicate that movement of phreatomagmatic explosion locations during maar-forming eruptions is common and must be incorporated into hazard scenarios.

\section{Circular maars}

Circular maars provide an additional opportunity to evaluate the range of footprint sizes and number of explosion locations. As described above, circular shapes can be produced by explosions that have a single lateral

Table 1 Spacing and footprint size distributions by size and shape breakdown

\begin{tabular}{|c|c|c|c|c|c|}
\hline Percentile & 10th & 25th & 50th & 75th & 90th \\
\hline Spacing (km) & 0.10 & 0.14 & 0.27 & 0.50 & 0.71 \\
\hline Footprint size $(\mathrm{km})$ & 0.27 & 0.47 & 0.66 & 1.0 & 1.85 \\
\hline \multirow[t]{3}{*}{ Footprint size $(\mathrm{km})+$ circles } & 0.27 & 0.47 & 0.66 & 1.0 & 1.82 \\
\hline & \multicolumn{2}{|c|}{ Spacing (km) } & \multicolumn{3}{|c|}{ Footprint size $(\mathbf{k m})$} \\
\hline & Average & Standard Dev & Average & Standard Dev & \\
\hline Ellipse & 0.19 & 0.16 & 1.14 & 0.97 & \\
\hline Peanut & 0.70 & 0.50 & 0.93 & 0.64 & \\
\hline Chain & 0.21 & 0.19 & 0.25 & 0.26 & \\
\hline Triple & 0.43 & 0.16 & 0.61 & 0.25 & \\
\hline Circles & - & - & 0.61 & 0.31 & \\
\hline
\end{tabular}




\section{Total Maar Area Relative to Eruption Spacing}
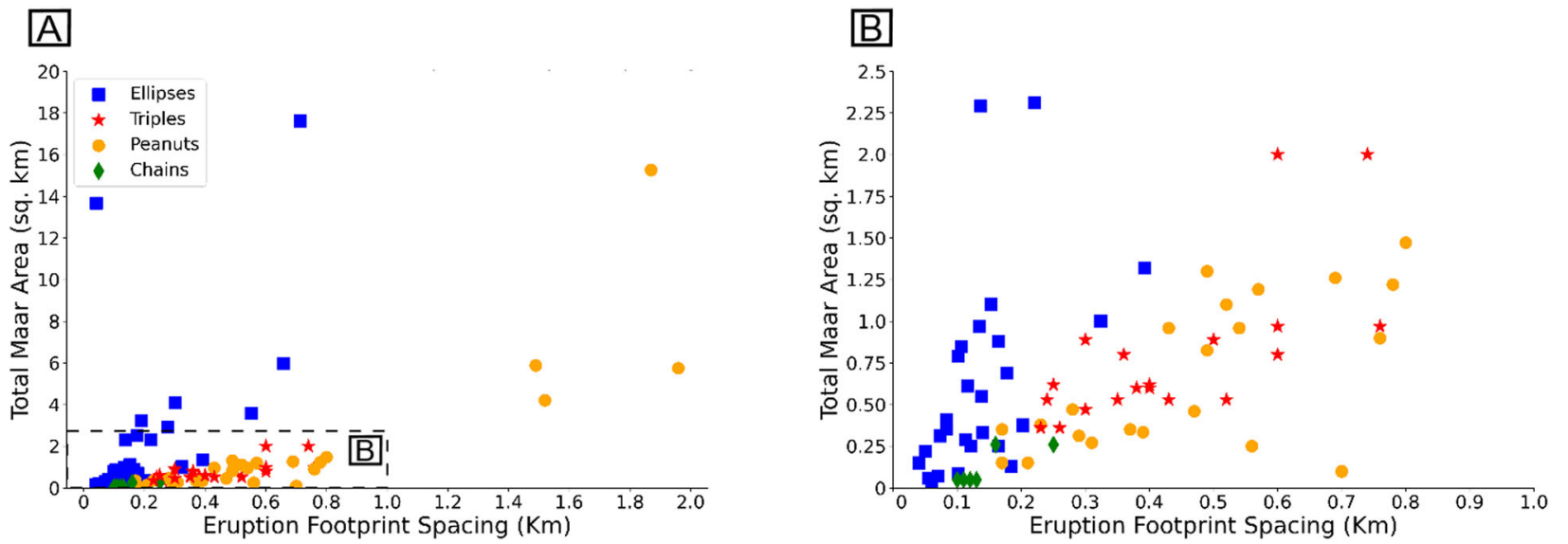

Fig. 5 Total maar area relative to component footprint spacing. a Full dataset, $\mathbf{b}$ only features less than $2.5 \mathrm{~km}^{2}$ and footprint spaces less than $1 \mathrm{~km}$

explosion location as well as those with explosion footprints that have their centers spaced less than the radius of the larger footprint (Fig. 2). Therefore, a large circular crater shape could be produced by numerous smaller footprints that are distributed such that all component footprints overlap by less than one radius around some central point (not necessarily the first crater). Reconstructing the history of such a crater can only be accomplished through stratigraphic analyses of deposits.

Evaluation of the literature on circular craters greater than $1 \mathrm{~km}$ reveals a paucity of circumcrater stratigraphic information (lack of exposure, lack of preservation, or not the focus of the study) needed to reconstruct vent positions. Two available examples are the Tepexitl in Serdan-Oriental Volcanic Field, and Hoya Estrada in Valle de Santiago, both in Mexico (Ross et al. 2017). Tepexitl has a major diameter of $1030 \mathrm{~m}$ and nearly continuous exposure along the interior crater wall. This exposure shows two eruptive phases that are similar around the entire circumference of the maar (AustinErickson et al. 2011) that would suggest minimal to no migration of the explosion location during the eruption. On the other hand, Hoya Estrada has evidence of lateral migration and is $1240 \mathrm{~m}$ across (Cano-Cruz and Carrasco-Núnez 2008). Interestingly, both cases involve rhyolitic compositions, although Hoya Estrada is bimodal with basaltic trachyandesite appearing in the later portion of the sequence associated with the lateral migration (Cano-Cruz and Carrasco-Núñez 2008). From studies to date, Tepexitl is the largest maar with evidence of limited lateral migration.

Experimental data provide an avenue for considering the threshold of the largest explosion footprints. Valentine et al. (2014) used the volume of intruded material as a proxy for available thermal energy and determined that most maars are likely produced by multiple explosions between $10^{9}$ and $10^{13} \mathrm{~J}$. In order to consider maximum anticipated phreatomagmatic explosion footprints, $10^{13}$

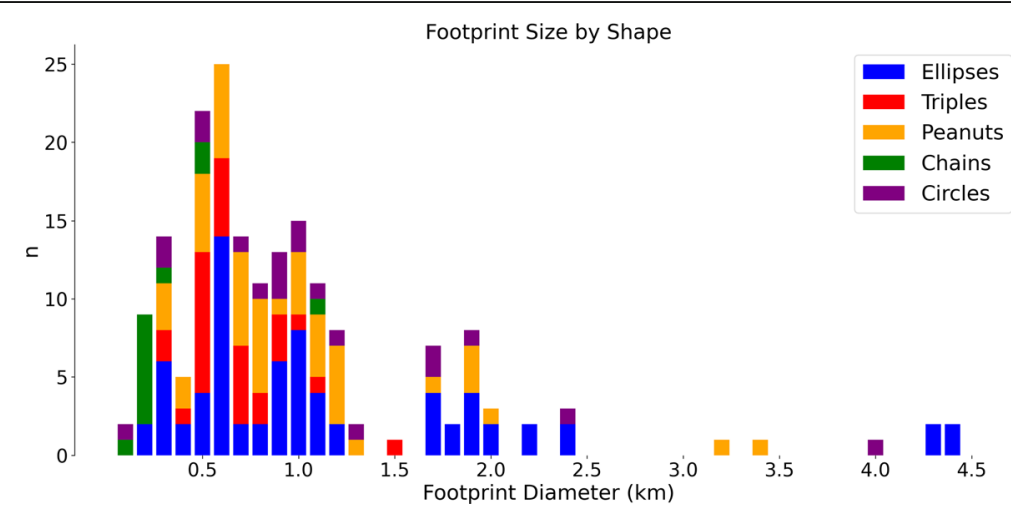

Fig. 6 Distribution of explosion footprint diameters by shape 
Table 2 Number of vent locations constrained by stratigraphic studies for phreatomagmatic dominated eruptions

\begin{tabular}{|c|c|c|c|}
\hline Maar name, Location & $\begin{array}{l}\text { Largest footprint dia. (km) / Total length } \\
(\mathrm{km})\end{array}$ & $\begin{array}{l}\text { Number of recognized } \\
\text { positions }\end{array}$ & References \\
\hline Ubehebe, CA, USA & $0.9 / 1.5$ & 13 & Fierstein and Hildreth 2017 \\
\hline Tecuitlapa, Mexico & $1.4 / 1.4$ & $>6$ & Ort and Carrasco Núñez 2009 \\
\hline Mt. Gambier, Australia & $1.2 / 3.0$ & 13 & Van Otterloo et al. 2013 \\
\hline Purrumbete, Australia & $2.8 / 2.8$ & $>3$ & Jordan et al. 2013 \\
\hline El Jagüey-La Breña & 1.4 / 2 spread & $>4$ & Aranda-Gomez et al. 1992 \\
\hline Atexcac, Mexico & $0.75 / 1.25$ & $9-16$ & $\begin{array}{l}\text { Lopez-Rojas and Carrasco-Núñez } \\
2015\end{array}$ \\
\hline Ukinrek, USA & $0.4 / 0.9$ & 3 (matches observations) & Ort et al. 2018 \\
\hline Tepexitl, Mexico & $1.0 / 1.0$ & 1 & Austin-Erickson et al. 2011 \\
\hline Loolmurwak, Tanzania & 0.87 & 1 & Mattsson and Tripoli 2011 \\
\hline $\begin{array}{l}\text { Deception Island, Antarctica } \\
1970^{a, b}\end{array}$ & $0.5 / 3 \mathrm{~km}$ spread & 13 & Pedrazzi et al. 2014 \\
\hline Kilburne Hole, USA & $? / 2.9$ & $\geq 3$ & Whelley et al. 2019 \\
\hline Rattlesnake Crater, USA & 1.5 / eroded & 1 & Whelley et al. 2019 \\
\hline Jeju Island, Korea ${ }^{c}$ & $\sim 0.3$ / eroded & $>3$ & Sohn and Park 2005 \\
\hline Hanauma Bay Tuff Ring, USA ${ }^{3}$ & $? />0.65$ & 3 & Rottas and Houghton 2012 \\
\hline
\end{tabular}

${ }^{a}$ Features produced separate craters in a single eruption. Not included in main analysis

${ }^{\mathrm{b}}$ Not included in MaarVLS due to poor image quality

${ }^{\mathrm{c}}$ Eroded feature not included in MaarVLS

and $10^{14} \mathrm{~J}$ explosion energies were evaluated using scaled-depth crater size estimates from Sonder et al. (2015) for the maximum crater size produced from those explosions at an optimum depth (explosion footprint). We then augmented these estimates to account for collapse by adding $60 \%$ to the diameter, resulting in estimated explosion footprint sizes of $\sim 520 \mathrm{~m}$ and $\sim 970 \mathrm{~m}$ respectively (Fig. 7). This augmentation acknowledges that reconstructed footprint sizes represent maximum diameters of possible footprints that contribute to crater shape and account for contributions to the footprint diameter including collapse related to the explosion, variations in host rock strength, and erosion. The majority of maars in MaarVLS (Graettinger 2018) and the majority of footprints measured in this study are less than 1 $\mathrm{km}$ in diameter. To produce a footprint of $\sim 2 \mathrm{~km}$ with a single explosion location and any related rim collapse, the required energy would be closer to $10^{15} \mathrm{~J}$ when compared with the estimates above. However, with the abundance of smaller footprint spacings (Fig. 4), these larger
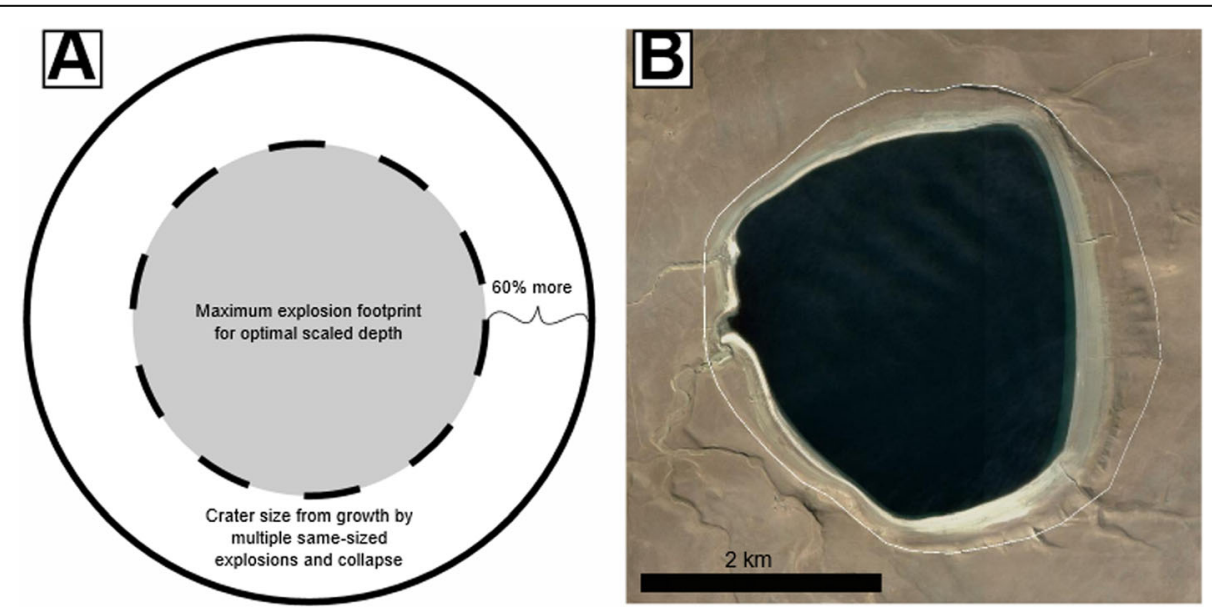

Fig. 7 a Calculation of potential crater size based on the footprint of an optimal scaled depth explosions of proposed maximum explosion energies use initial crater sizes from Sonder et al. (2015) with an additional 60\% growth through collapse from additional explosions within the footprint and unstable walls based on observations during explosion experiments. b Potrok, Argentina, is the largest circular crater in MaarVLS. The crater rim is outlined in white on an image from Google Earth CNES/Airbus and Maxar Technologies 
explosion energies are not necessarily required to produce large craters. Other efforts to constrain phreatomagmatic explosion energies also pointed to values of between $10^{11}$ and $10^{14} \mathrm{~J}$ (Self et al. 1980; Raue 2004; van Otterloo et al. 2013; Graettinger and Valentine 2017; Fitch and Fagents 2020). Taddeucci et al. (2010) evaluated circular components similar to explosion footprints of the Colli Albani maars to produce total energy estimates (multiple explosions) to be $10^{15}-10^{17} \mathrm{~J}$ (Taddeucci et al. 2010), but they did not account for any contributions from collapse.

If we consider the abundance of circular maar craters less than $1 \mathrm{~km}$ in diameter, the preponderance of explosion footprints $1 \mathrm{~km}$ and smaller, and stratigraphic evidence we can reasonably consider that a $1 \mathrm{~km}$ crater can be produced without significant lateral migration (greater than $100 \mathrm{~m}$; Loolmurwak, Rattlesnake Crater, and Tepexitl; Table 2; Fig. 6). Therefore, we will evaluate circular craters larger than $1 \mathrm{~km}$ (12 craters in MaarVLS) as the product of explosion footprints up to $1 \mathrm{~km}$ in diameter.

Using the largest circular maar crater in the MaarVLS database, Potrok, Argentina (3.9 km in diameter), we can use this $1 \mathrm{~km}$ footprint threshold to estimate the minimum number of explosion positions to produce such a larger circular crater. Four 1-km footprints in a line could produce a shape with this diameter, but another four would be needed to produce a crater with the same Aspect Ratio as a circle. To completely cover the area of Laguna Potrok with explosion footprints without overlap, ten 1-km-diameter footprints are required. If overlap of footprints (up to 1 radius, consistent with experimental observations) is allowed, 20 footprints would be required to produce the $3.9 \mathrm{~km}$ diameter circular crater. Though oversimplified, this estimate can be the basis for bounding the potential relocation of hazards in the absence of other data.

\section{Implications for hazards}

Crater shape analysis of 94 Quaternary maar craters with unique shape solutions provides the first opportunity to establish common trends in the minimum number of explosion positions, associated minimum energies, and extent of lateral migration of explosion sites during maar-forming eruptions. As the areal extent affected by hazards around an eruptive vent has been identified as a key input for numerical models and hazard simulations (Hayes et al. 2020), the quantitative constraint on the contributing explosion footprints and spacing of these different explosion locations in this study represents a valuable set of inputs for eruption simulations. Instead of noting that lateral migrations of explosions during an eruption are possible, eruption scenarios can incorporate numbers of vent areas and spacing distances based on global estimates (Tables 1,2), and refine their estimates based on local analyses on the volcanic field of interest.

Maar crater shape analysis indicates that the majority (>60\%) of studied Quaternary maars are the product of three or more lateral vent relocations with spacing distances greater than the initial crater radius. Crater shapes with unique solutions indicate that individual explosion positions (epicenters) are predominantly four or less, but the number of individual shifts in explosion position among and between those unique locations may be as high as 16 (Table 2), or even 20 (Potrok). Consequently, even conservative eruption scenarios should include at least three shifts of explosion locations with distances of more than $100 \mathrm{~m}$ during maar-forming eruptions. While our analysis does not include magmatic phases of the eruptions, as they would not produce explosion footprints, magmatic phases are common in maar-forming eruptions (Ross et al. 2017; Graettinger and Valentine 2017) and may also move around within the resulting crater.

The spacing measurements presented here reflect the maximum distance that the explosion position can travel and still produce a single crater based on observed maar crater shapes. Although very large peanut maar shapes exist, the vast majority of the spacing measurements reflect footprint spacing distances of less than $0.8 \mathrm{~km}$. This value, or another derived from a preferred percentile threshold (Table 1), could be used for developing larger or dynamic hazard zones to include the possibility of migrating explosion locations. As ballistic hazard zones are typically defined by the maximum distance that ballistic blocks travel (Fitzgerald et al. 2017), this zone could be augmented by a selected percentile spacing for maar eruptions as deemed appropriate for a given volcanic field to reflect the potential for lateral relocation of explosive hazards during a maar-forming eruption (i.e. 75th percentile of $550 \mathrm{~m}$; Table 1).

Crater shape categories also highlight the common occurrence of lateral shifts of explosion location in more than one direction, that is, not strictly along a lineation like a feeder dike. A third of maars in MaarVLS have more than one direction of lateral migration represented by two directions of elongation including triples and many convolute crater shapes. This is also seen in eruption observations, such as the Ukinrek eruption, which started as a fissure eruption (Kienle et al. 1980; Ort et al. 2018), but the east crater grew to be elongated in a direction perpendicular to the direction of fissure propagation but parallel to some regional faults (Ort et al. 2018). Observations from Nichols and Graettinger (in press) showed only $31 \%$ of non-circular maars studied had elongations in the same direction as regional stress indicators or the alignment of vents in which they were situated. Consequently, eruption scenarios should 
allow for hazard migration to not be limited to the orientation of a feeder dike or regional stress indicators. This may require that hazard zones be larger at the start of the eruption and adaptive boundaries may be possible during eruptive events.

Further interrogation of explosion footprint data confirmed that maars may be produced by similarly sized or dissimilarly sized explosion footprints (Fig. 1A). Half of crater shapes with unique solutions (peanuts, chains, triples) have at least one footprint that is more than $0.2 \mathrm{~km}$ smaller than the next largest footprint even though the symmetry of elliptical crater shapes (the most common unique crater shape) implies two similarly sized footprints do occur (Fig. 3). While crater footprints are only a minimum constraint of the explosion energy, this variability in footprint sizes in a single maar indicates that variability in explosion sizes and/or relative depths should also be considered in eruption scenarios.

One final consideration is that some instances of lateral shifts in explosion positions can produce inclined eruptive jets. Cratering experiments that used chemical explosives to simulate migrating subsurface explosions revealed the influence of pre-existing craters on jet behavior (Taddeucci et al. 2013; Graettinger et al. 2014). Importantly, lateral relocation of explosion positions beneath the sloped inner crater wall produced inclined jets that transported abundant ballistic particles to greater distances than an equivalent vertical jet (Graettinger et al. 2015; Valentine et al. 2015). Based on experiments, this scenario occurred when the spacing between explosion locations was approximately equal to the footprint radius. This inclined jet scenario represents a much larger and more complicated hazard area (Fig. 8). However, this hazard is present in a specific range of conditions in which spacing is close to the radius of the previous crater. This corresponds to eruption scenarios that produce circular, elliptical, and likely teardrop crater shapes. Convoluted shapes may very well involve spacings close to the radius of previous footprints, but we cannot constrain the number of these events from shape alone. Elliptical shapes and teardrop shapes represent $13 \%$ of the MaarVLS database, with circles of all sizes contributing another $12 \%$ of the total population, so lateral jets may occur in more than a quarter of maar eruptions. As spacing increases, later explosions produce vertical jets because they do not 'feel' the influence of the previous crater. While larger spacings can relocate the center of activity, only some shifts in explosion position might produce a directed hazard.

Importantly for hazard considerations, this analysis only focused on maars where a single crater (where a continuous rim surrounds one or more depressions) was produced by an eruption and does not include measurements where the shift in explosion location resulted in the formation of separate craters in a crater complex. Such craters would involve explosion spacing that is greater than two times the radius of previous explosion footprints. Two historic maar-forming eruptions in Table 2 did not form a single final crater, but rather a crater complex (Pedrazzi et al. 2014; Ort et al. 2018). An estimate of the relative frequency of eruptions in which spacing is greater than the diameter of explosion footprints requires additional detailed stratigraphic and more geochronological studies of maars.

\section{Conclusions and suggestions}

Analysis of maar crater shapes using explosion footprints provides unprecedented insight into the number and distance of lateral shifts of explosion locations in maarforming eruptions. The variable position of eruption hazards is important to constrain for use in eruption scenarios and numerical simulations of eruptive events. The 241 intact Quaternary maars evaluated here indicate that most maars $(60 \%)$ require three or more shifts in explosion position to form, but evidence for as many as 20 movements may be responsible for the largest maars. The variable explosion positions that are preserved in crater shapes can require more than one size of explosion footprint in more than $30 \%$ of cases and can go in multiple directions or return to previously occupied locations.

Our analysis shows that most explosion locations are spaced less than $0.8 \mathrm{~km}$ apart, with a mean of 0.39 and a standard deviation of 0.36, although spacings as large as $2 \mathrm{~km}$ may be possible. The explosion footprints contributing to the preserved maar crater shapes are mostly less than $1 \mathrm{~km}$ in diameter, with a mode of $0.6 \mathrm{~km}$ in diameter. This may indicate that many maar craters are produced by multiple explosions and the minimum explosion energies would be equal to or greater than $10^{13}-10^{14} \mathrm{~J}$. Constraining the maximum explosion footprint diameters, and the minimum number of shifts in explosion locus responsible for maar crater shapes is very valuable to establishing hazard zones for future eruptions.

While crater shape analysis allows for quantitative assessment of only $30 \%$ of the MaarVLS database, spacing and footprint statistics from 94 maars from over 40 volcanic fields supported by qualitative data from another 147 maars is a significant advance in our understanding of the scale and minimum frequency of lateral migration in maar-forming eruptions and provides quantitative inputs for hazard models and eruption scenarios needed to prepare for future maar-forming eruptions.

Future work is needed to address the causes of these relocations, particularly to identify the influences on individual volcanic fields. Areas of exploration into these causes include of the hydrology related to past maar 


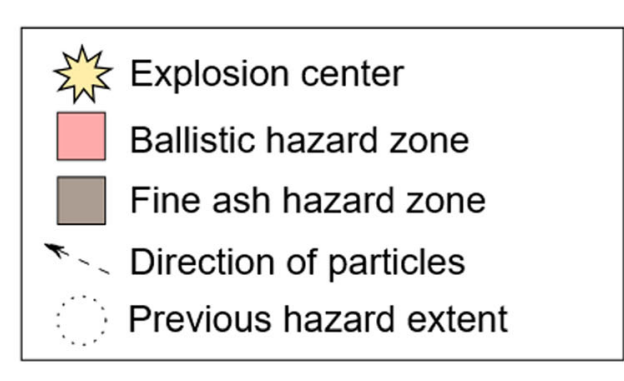

\section{Single explosion location}

A
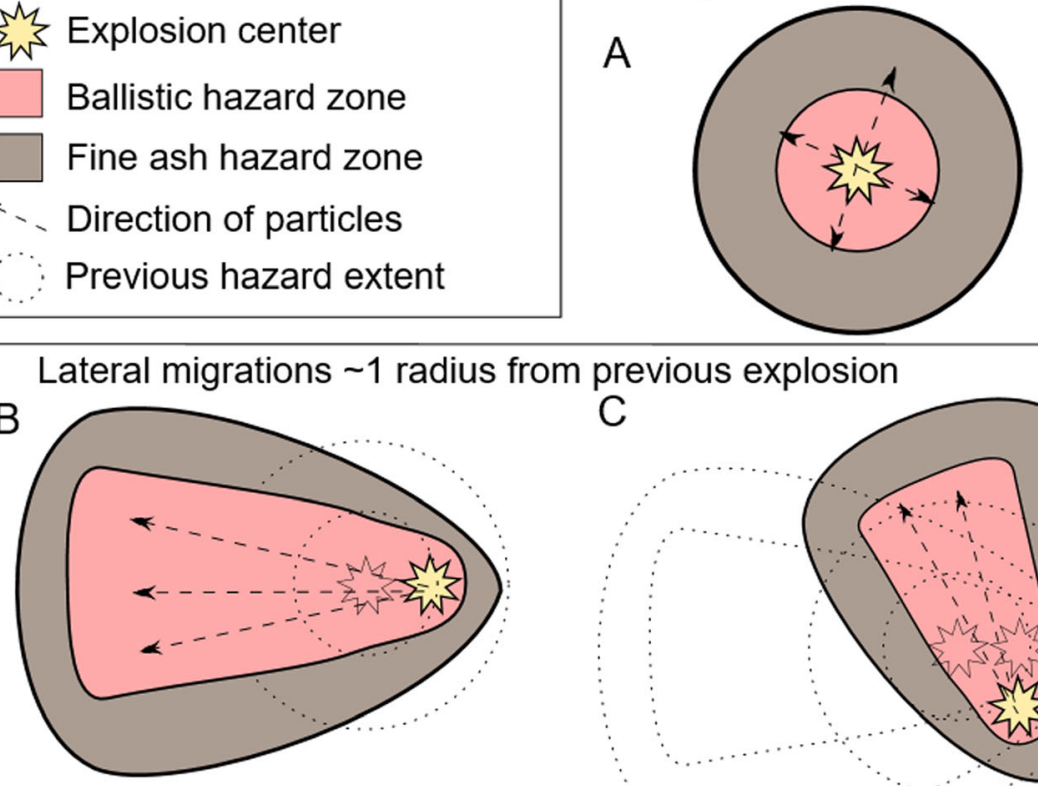

$\mathrm{D}$

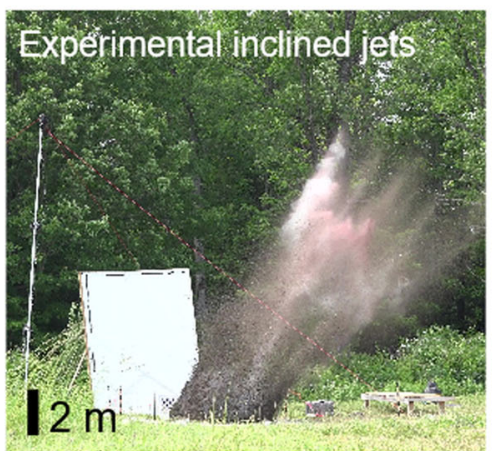

previous explosion

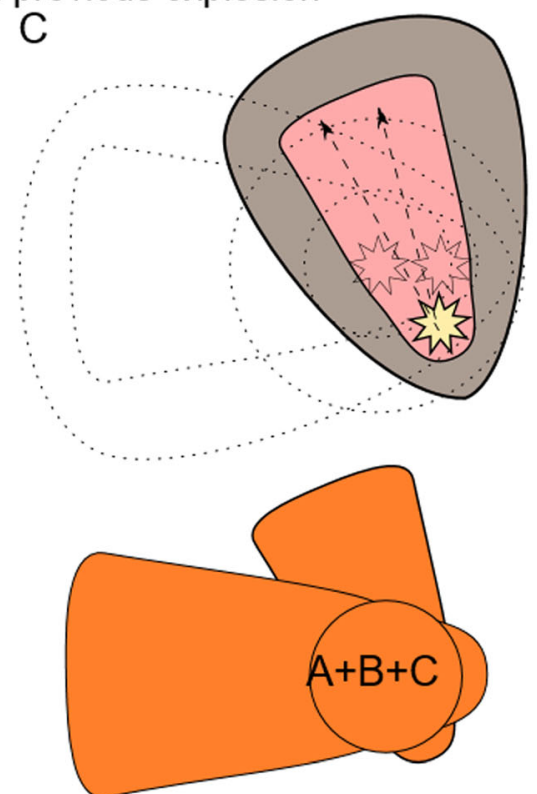

Cumulative ballistic zone

E Lateral migrations $>1$ radius from previous explosion
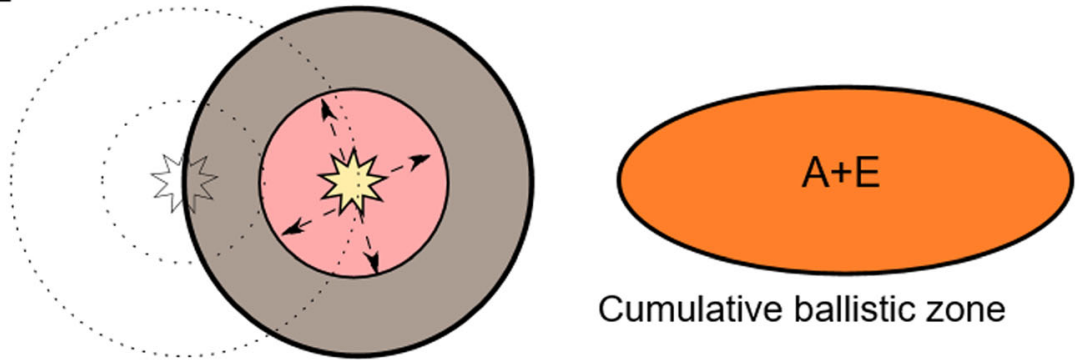

Cumulative ballistic zone

Fig. 8 Simplified schematics of the distribution of hazard areas around crater growth eruption scenarios to highlight the potential complications caused by lateral relocation of explosion positions. a Hazards are evenly distributed when explosion locations are laterally fixed. $\mathbf{b}$ Lateral migrations $\sim 1$ footprint radius away from the first crater results in lateral jets through the crater wall and larger asymmetrical hazard areas. $\mathbf{c}$ Continued lateral migration $\sim 1$ radius can result in very complicated hazard areas like in shape $A+B+C$. $\mathbf{d}$ Example inclined jet produced by explosion experiments un pre-existing crater walls (Graettinger et al. 2015). e Explosion locations greater than one radius and less than 2 radii away from the previous epicenter produced larger hazard areas and compound craters

eruptions (Kereszturi et al. 2017), regional structures and host rock materials (Nichols and Graettinger in press), and studies of near surface magma transport (magma flux, geometry; Muirhead et al. 2016, Le
Corvec et al. 2018). Additional field work, geochronology, and numerical simulations on these complex interactions will support preparation for the next maar-forming eruption. 


\section{Abbreviations}

AR: Aspect Ratio; EL: Elongation; IC: Isoperimetric Circularity; MaarVLS: Maar Volcano Location and Shape; R1: Radius of largest footprint for a crater; R2: Radius of a footprint that is less than or equal to R1

\section{Supplementary Information}

The online version contains supplementary material available at https://doi. org/10.1186/s13617-021-00103-w.

\section{Additional file 1}

\section{Acknowledgements}

We wish to acknowledge the UMKC Undergraduate Research Office for their financial support and opportunities to involve undergraduates in projects like this. Additionally, the authors express gratitude to Greg Valentine for comments that helped improve a preliminary version of the manuscript. Similar discussions with the rest of the UMKC MELT research team were valuable. Reviews by M. Ort and A. Verolino and editorial oversight by S. Jenkins are greatly appreciated. ASTER GDEM is a product of METI and NASA.

\section{Authors' contributions}

The project was conceived of by Graettinger. Data collection, figure production, and manuscript preparation and editing done by Graettinger and Bearden.

\section{Funding}

This research was funded in part by UMKC undergraduate research funds SUROP and SEARCH to A. Bearden.

\section{Availability of data and materials}

The dataset supporting the conclusions of this article is included within the article and its additional files. Additional related files of the original MaarVLS dataset are available in the vhug.org repository. https://vhub.org/ resources/4365

Additional file 1. xls includes all maars quantitatively evaluated in this study and is accompanied by a reference list for all maars included in the study.

\section{Declaration}

\section{Competing interests}

Not applicable.

Received: 2 November 2020 Accepted: 18 February 2021

Published online: 13 April 2021

\section{References}

Ang PS, Bebbington MS, Lindsay JM, Jenkins SF (2020) From eruption scenarios to probabilistic volcanic hazard analysis: an example of the Auckland volcanic field, New Zealand. J Volcanol Geotherm Res 397:106871. https://doi. org/10.1016/j.jvolgeores.2020.106871

Aranda-Gomez JJ, Luhr JF (1996) Origin of the Joya Honda maar, San Luis Potosi, Mexico. J Volcanol Geotherm Res 74:1-18

Aranda-Gomez JJ, Luhr JF, Pier JG (1992) The La Brena-El Jaguey maar complex, Durango, Mexico: I. geological evolution. Bull Volcanol 54:393-404

Austin-Erickson A, Ort MH, Carrasco-Núñez G (2011) Rhyolitic phreatomagmatism explored: Tepexitl tuff ring (eastern Mexican Volcanic Belt). J Volcanol Geotherm Res 201:325-341. https://doi.org/10.1016/j.jvolgeores.2010.09.007

Avellan DR, Macias JL, Pardo N, Scolamacchia T, Rodriguez D (2012) Stratigraphy, geomorphology, geochemistry and hazard implications of the Nejapa volcanic field, western Managua, Nicaragua. J Volcanol Geotherm Res 213214:51-71. https://doi.org/10.1016/j.jvolgeores.2011.11.002

Blaikie T, Ailleres L, Betts PG, Cas RAF (2014) A geophysical comparison of the diatremes of simple and complex maar volcanoes, newer Volcanics Province, South-Eastern Australia. J Volcanol Geotherm Res 276:64-81. https://doi.org/1 0.1016/j.jvolgeores.2014.03.001

Cano-Cruz M, Carrasco-Núñez G (2008) Evolución de un cráter de explosión (maar) riolítico: Hoya de Estrada, campo volcánico Valle de Santiago, Guanajuato, México. Revista Mexicana de Ciencias Geológicas 25:549-564
Fierstein J, Hildreth W (2017) Eruptive history of the Ubehebe crater cluster, Death Valley, California. J Volcanol Geotherm Res 335:128-146. https://doi. org/10.1016/j.jvolgeores.2017.02.010

Fitch EP, Fagents SA (2020) Using the characteristics of rootless cone deposits to estimate the energetics of explosive lava-water interactions. Bull Volcanol 82 83. https://doi.org/10.1007/s00445-020-01422-3

Fitzgerald RH, Kennedy BM, Wilson TM, Leonard GS, Tsunematsu K, Keys H (2017) The communication and risk management of volcanic ballistic hazards. Advances in Volcanology. https://doi.org/10.1007/11157_2016_35

Graettinger AH (2018) Trends in maar crater size and shape using the global maar volcano location and shape (MaarVLS) database. J Volcanol Geotherm Res 357:1-13. https://doi.org/10.1016/j.jvolgeores.2018.04.002

Graettinger AH, Valentine G, Sonder I (2016) Recycling in debris-filled volcanic vents. Geology 44:811-814. https://doi.org/10.1130/G38081.1

Graettinger AH, Valentine GA (2017) Evidence for the relative depths and energies of phreatomagmatic explosions recorded in tephra rings. Bull Volcanol 79:88. https://doi.org/10.1007/s00445-017-1177-x

Graettinger AH, Valentine GA, Sonder I (2015) Circum-crater variability of deposits from discrete, laterally and vertically migrating volcanic explosions: experimental evidence and field implications. J Volcanol Geotherm Res 308: 61-69. https://doi.org/10.1016/j.jvolgeores.2015.10.019

Graettinger AH, Valentine GA, Sonder I, Ross P-S, White JDL, Taddeucci J (2014) Maar-diatreme geometry and deposits: subsurface blast experiments with variable explosion depth. Geochemistry Geophysics Geosystems 15. https:// doi.org/10.1002/2013GC005198

Hayes JL, Wilson TM, Deligne NI, Lindsay JM, Leonard GS, Tsang SWR, Fitzgerald RH (2020) Developing a suite of multi-hazard volcanic eruption scenarios using an interdisciplinary approach. J Volcanol Geotherm Res 392. https://doi. org/10.1016/j.jvolgeores.2019.106763

Jordan SC, Cas RAF, Hayman PC (2013) The origin of a large (<3 km) maar volcano by coalescence of multiple shallow craters: Lake Purrumbete maar, southeastern Australia. J Volcanol Geotherm Res 254:5-22. https://doi.org/1 0.1016/j.jvolgeores.2012.12.019

Kereszturi G, Bebbington M, Nemeth K (2017) Forecasting transitions in monogenetic eruptions using the geologic record. Geology 45:283-286. https://doi.org/10.1130/G38596.1

Kienle J, Kyle PR, Self S, Motyka RJ, Lorenz V (1980) Ukinrek maars, Alaska, I. April 1977 eruption sequence petrology and tectonic setting. J Volcano Geotherm Res 7:11-37

Le Corvec N, Muirhead JD, White JDL (2018) Shallow magma diversions during explosive diatreme-forming eruptions. Nat Commun 9:1459. https://doi.org/1 0.1038/s41467-018-03865-x

Lefebvre NS, White JDL, Kjargaard BA (2013) Unbedded diatreme deposits reveal maar-diatreme forming eruptive processes: standing rocks west, Hopi buttes, Navajo nation, USA. Bull Volcanol 75:739. https://doi.org/10.1007/s00445-0130739-9

Lopez-Rojas M, Carrasco-Núñez G (2015) Depositional facies and migration of the eruptive loci for Atexcac axalapazco (Central Mexico): implications for the morphology of the crater. Revista Mexicana de Ciencias Geologicas 32:377394

Mattsson HB, Tripoli BA (2011) Depositional characteristics and volcanic landforms in the Lake Natron-Engaruka monogenetic field, northern Tanzania. J Volcanol Geotherm Res 203:23-34. https://doi.org/10.1016/j. jvolgeores.2011.04.010

Muirhead JD, van Eaton AR, Re G, White JDL, Ort MH (2016) Monogenetic volcanoes fed by interconnected dikes and sills in the Hopi buttes volcanic field, Navajo nation, USA. Bull Volcanol 78:11. https://doi.org/10.1007/s00445016-1005-8

Nemeth, K, Kereszturi, G.(2015) Monogenetic volcanism: personal views and discussion. International Journal of Earth Sciences (Geol Rundsch) 103:213146. https://doi.org/10.10047/s00531-015-1243-6

Nichols C, Graettinger AH (in press) The influence of regional stress and structural control on the shape of maar craters. Volcanica (doi anticipated soon)

Ort MH, Carrasco Núñez G (2009) Lateral vent migration during phreatomagmatic and magmatic eruptions at Tecuitlapa maar, east-Central Mexico. J Volcanol Geotherm Res 181:67-77. https://doi.org/10.1016/j. jvolgeores.2009.01.003

Ort MH, Lefebvre NS, Neal CA, McConnell VS, Wohletz KH (2018) Linking the Ukinrek 1977 maar-eruption observations to the tephra deposits: new insights into maar depositional processes. J Volcanol Geotherm Res 360:3660. https://doi.org/10.1016/j.jvolgeores.2018.07.005 
Pedrazzi D, Aguirre Diaz G, Bartolini S, Mari J, Geyer A (2014) The 1970 eruption on Deception Island (Antarctica): eruptive dynamics and implications for volcanic hazards. J Geol Soc. https://doi.org/10.1144/jgs2014-015

Pirrung M, Buchel G, Lorenz V, Treutler H-C (2008) Post-eruptive development of the Ukinrek east maar since its eruption in 1977 a.D. in the periglacial area of south-West Alaska. Sedimentology 55:305-334. https://doi.org/10.1111/j.13 65-3091.2007.00900.x

Raue $\mathrm{H}$ (2004) A new model for the fracture energy budget of phreatomagmatic explosions. J Volcanol Geotherm Research 129:99-108. https://doi.org/10.101 6/S0377-0273(03)00234-8

Ross P-S, Carrasco-Núñez G, Hayman P (2017) Felsic maar-diatreme volcanoes: a review. Bull Volcanol 79. https://doi.org/10.1007/s00445-016-1097-1

Rottas KM, Houghton BF (2012) Structure, stratigraphy, and eruption dynamics of a young tuff ring: Hanauma Bay, O'ahu, Hawai'l. Bull Volcanol 74:1693-1697. https://doi.org/10.1007/s00445-012-0624-y

Rouwet D, Chiarini V (2013) VOLCADA-the first collaborative database on Volcanic Lakes. https://vhub.org/resources/2822

Self S, Kienle J, Huot J-P (1980) Ukinrek maars, Alaska, II. Deposits and formation of the 1977 craters. J Volcanol Geotherm Res 7:39-65

Sohn YK, Park KH (2005) Composite tuff ring/cone complexes in Jeju Island, Korea: possible consequences of substrate collapse and vent migrations. J Volcanol Geotherm Res 141:157-175. https://doi.org/10.1016/j.jvolgeores.2 004.10 .003

Sonder I, Graettinger AH, Valentine GA (2015) Scaling multiblast craters: General approach and application to volcanic craters. J Geophysical Res: Solid Earth 120:9. https://doi.org/10.1002/2015jb012018

Sweeney MR, Valentine GA (2015) Transport and mixing dynamics from explosions in debris-filled volcanic conduits: numerical results and implications for maar-diatreme volcanoes. Earth Planet Sci Lett 425:64-67. https://doi.org/10.1016/j.epsl.2015.05.038

Taddeucci J, Sottili G, Palladino DM, Ventura G, Scarlato P (2010) A note on maar eruption energetics: current models and their application. Bull Volcanol 72: 75-83. https://doi.org/10.1007/s00445-009-0298-2

Taddeucci J, Valentine GA, Sonder I, White JDL, Ross P-S, Scarlato P (2013) The effect of pre-existing craters on the initial development of explosive volcanic eruptions: an experimental investigation. Geophys Res Lett 40:507-510. https://doi.org/10.1002/grl.50176

Valentine GA, Graettinger AH, Macorps E, Ross P-S, White JDL, Döhring E, Sonder I (2015) Experiments with vertically and laterally migrating subsurface explosions with applications to the geology of phreatomagmatic and hydrothermal explosion craters and diatremes. Bull Volcanol 77. https://doi. org/10.1007/s00445-015-0901-7

Valentine GA, Graettinger AH, Sonder I (2014) Explosion depths for phreatomagmatic eruptions. Geophys Res Lett 41:3045-3051. https://doi. org/10.1002/2014GL060096

Valentine GA, White JDL, Ross P-S, Graettinger AH, Sonder I (2017) Updates to concepts on phreatomagmatic maar-diatremes and their pyroclastic deposits. Front Earth Sci 5. https://doi.org/10.3389/feart.2017.00068

van Otterloo J, Cas RAF, Sheard MF (2013) Eruption processes and deposit characteristics at the monogenetic Mt. Gambier volcanic complex, SE Australia: implications for alternative magmatic and phreatomagmatic activity. Bull Volcanol 75:737

Whelley P, Enriquez F, Richardson JA, Hurtado JM, Young K, Bleacher JE (2019) How many explosions make a maar crater? American Geophysical Union Annual Meeting Programs and Abstracts, P31C-3472

White JDL, Ross P-S (2011) Maar-diatreme volcanoes: a review. J Volcanol Geotherm Res 201:1-29. https://doi.org/10.1016/j.jvolgeores.2011.01.010

\section{Publisher's Note}

Springer Nature remains neutral with regard to jurisdictional claims in published maps and institutional affiliations.

Ready to submit your research? Choose BMC and benefit from:

- fast, convenient online submission

- thorough peer review by experienced researchers in your field

- rapid publication on acceptance

- support for research data, including large and complex data types

- gold Open Access which fosters wider collaboration and increased citations

- maximum visibility for your research: over $100 \mathrm{M}$ website views per year

At BMC, research is always in progress.

Learn more biomedcentral.com/submissions 